\title{
HUBUNGAN USIA PENGENALAN SAYUR DAN BUAH DENGAN TINGKAT KONSUMSI SAYUR DAN BUAH PADA ANAK PRASEKOLAH USIA 3-5 TAHUN
}

\author{
Tri Damayanti ${ }^{1}$, Etisa Adi Murbawani ${ }^{1}$, Deny Yudi Fitranti ${ }^{1}$ \\ ${ }^{1}$ Departemen Ilmu Gizi, Fakultas Kedokteran, Universitas Diponegoro \\ Jln. Prof. H. Soedarto, SH., Semarang, Telp (024) 8453708, Email : gizifk@ undip.ac.id
}

\begin{abstract}
Background: Vegetables and fruits consumption levels in preschool children is below from recommendation. The introduction of vegetables and fruits in children by parents is very important in the early development of acceptance and diet of vegetables and fruits that will be applied until the child is mature. This study aims to determine the correlation between the age of introduction vegetables and fruits with level consumption of vegetables and fruits in preschool children aged 3-5 years.

Methods: A cross-sectional study design with 53 preschoolers aged 3-5 years was chosen by Consecutive Sampling. The research was conducted in urban village Wonotingal and Candisari (working area of Pukesmas Kagok), Semarang. Data age of introduction vegetable and fruit was obtained through questionnaire interview. Data of vegetable and fruit consumption levels were obtained through SQ-FFQ (Semi-Quantitative Food Frequency Quesioner). Analysis used Rank Spearman correlation test.

Results: Median age of introduction vegetable 8.17 months and fruit age of 7.6 months. Level of vegetable consumption in children was average 84,78 gr/day and fruit average 98,94 gr/day. Age of introduction vegetable was not related to vegetable consumption level $(p=0.193)$ and age of introduction fruit was related to fruit consumption level $(p=0.045)$. Multivariate analysis showed that 20,5\% fruit availability had an effect on fruit consumption level.

Conclusion: There was no association between age of introduction vegetable and vegetable consumption level, while age of introduction fruit was negative association with fruit consumption level in preschool children aged 3-5 years.
\end{abstract}

Keywords: Age of introduction vegetables, age of introduction fruits, vegetables consumption level, fruit consumption level, preschool children aged 3-5 years.

\begin{abstract}
ABSTRAK
Latar Belakang : Tingkat konsumsi sayur dan buah pada anak prasekolah dibawah dari angka yang direkomendasikan. Pengenalan sayur dan buah pada anak oleh orang tua sangat penting dalam pengembangan awal penerimaan dan pola makan sayur dan buah yang akan diterapkan sampai anak tersebut dewasa. Penelitian ini bertujuan untuk mengetahui hubungan antara usia pengenalan sayur dan buah dengan tingkat konsumsi sayur dan buah pada anak prasekolah usia 3-5 tahun.

Metode : Desain penelitian cross-sectional dengan 53 anak prasekolah usia 3-5 tahun dipilih secara Consecutive Sampling. Penelitian dilaksanakan di Kelurahan Wonotingal dan Kelurahan Candisari (wilayah kerja Pukesmas Kagok), Semarang. Data usia pengenalan sayur dan buah diperoleh melalui wawancara kuesioner. Data tingkat konsumsi sayur dan buah dipeoleh melalui SQ-FFQ (Semi-Quantitative Food Frequency Quesioner. Analisis menggunakan uji korelasi Rank Spearman.

Hasil : Median usia pengenalan sayur 8,17 bulan dan buah usia 7,6 bulan. Median tingkat konsumsi sayur pada anak sebesar 84,78 gr/hari dan buah sebesar 98,94 gr/hari. Usia pengenalan sayur tidak berhubungan dengan tingkat konsumsi sayur $(\mathrm{p}=0,193)$ dan usia pengenalan buah berhubungan dengan tingkat konsumsi buah $(p=0,045)$. Analisis multivariat menunjukkan bahwa sebesar 20,5\% ketersediaan buah berpengaruh terhadap tingkat konsumsi buah.

Simpulan : Tidak terdapat hubungan antara usia pengenalan sayur dengan tingkat konsumsi sayur, sedangkan usia pengenalan buah berhubungan negatif dengan tingkat konsumsi buah pada anak prasekolah usia 3-5 tahun.
\end{abstract}

Kata Kunci : Usia pengenalan sayur, Usia pengenalan buah, Tingkat konsumsi sayur, Tingkat konsumsi buah, Anak prasekolah usia 3-5 tahun

\section{PENDAHULUAN}

Anak usia prasekolah dimulai dari usia 3 sampai 5 tahun, ${ }^{1}$ disebut sebagai masa keemasan (the golden age) karena terjadi beberapa perubahan baik fisik maupun psikologis dari anak tersebut. ${ }^{2}$ Berbanding terbalik dengan pertumbuhan tubuh, perkembangan psikologis anak berkembang secara pesat. ${ }^{1}$ Hal ini dapat dilihat dari adanya perubahan sikap dan perilaku anak dalam pemilihan makanan termasuk konsumsi sayur dan buah. Berdasarkan penelitian Tahun 2007, menyatakan bahwa anak yang pemilih terhadap makanan cenderung memiliki asupan sayur dan buah yang rendah. ${ }^{3}$ 
Data di Amerika menyebutkan bahwa konsumsi sayur dan buah pada anak prasekolah hanya terpenuhi sekitar 25\% perhari dari total rekomendasi sebesar $80 \%$ perhari. ${ }^{4}$ Penelitian Tahun 2010 di TK Supriyadi Semarang, sebanyak 93,6\% sampel mengkonsumsi sayur dalam kategori kurang dengan rata-rata konsumsi 73,5 g/hari, sedangkan sebesar $100 \%$ sampel memiliki rata-rata konsumsi buah sebesar 58,6 gr/hari masih kurang dari anjuran. ${ }^{5}$ Dampak yang ditimbulkan apabila konsumsi sayur dan buah rendah dalam jangka pendek yaitu sembelit atau konstipasi. Dampak jangka panjang yang ditimbulkan seperti penyakit kardiovaskuler, stroke, obesitas, diabetes melitus, kanker usus dan dislipidemia. $^{6}$

Asupan sayur dan buah dalam jumlah yang cukup mampu menurunkan obesitas atau kelebihan berat badan karena serat mengandung energi dan kalori yang relatif rendah, serta menimbulkan rasa kenyang lebih lama. Sinyal rasa kenyang dikirimkan ke otak setelah 20 menit, karena terjadi peningkatan waktu pengunyahan dan waktu pengosongan lambung sehingga secara perlahan orang tersebut tidak akan tertarik dengan makanan bahkan akan berhenti untuk makan serta menurunkan asupan makanannya. ${ }^{7}$ Selain itu, sayur dan buah juga mengandung vitamin, mineral dan antioksidan yang berguna sebagai sistem imun atau sistem pertahanan tubuh dari radikal bebas. Anjuran konsumsi sayur dan buah untuk orang Indonesia menurut Pedoman Gizi Seimbang 2014, sebesar 300-400 g per orang per hari untuk balita dan anak usia sekolah, sekitar duapertiga dari jumlah tersebut adalah porsi sayur. ${ }^{8,9}$ Alasan rendahnya konsumsi sayur dan buah pada anak karena adanya kandungan zat phenylthiocarbamide yang menyebabkan rasa pahit pada sayur, sedangkan buah karena tekstur dan rasa asam dari beberapa buah. ${ }^{10}$

Kebiasaan atau perilaku dari orang tua termasuk dalam mengendalikan ketersediaan dan aksesibilitas sayur dan buah di rumah berhubungan dengan asupan sayur dan buah pada anak-anak. ${ }^{3}$ Sesuai dengan penelitian pada Tahun 2004 yang menyatakan bahwa orang tua menjadi pengaruh utama pada pengembangan pilihan serta pola makan pada anak yang dikenalkan oleh orang tua sejak usia dini. ${ }^{11}$ Pengenalan tidak sekedar dalam pengulangan paparan asupan sayur dan buah melainkan penggunaan variasi sayur dan buah secara berulang setiap 3-5 hari. ${ }^{12}$ Faktor-faktor lain yang mempengaruhi konsumsi sayur dan buah yaitu usia pengenalan, riwayat ASI, kebiasaan ibu selama hamil, ketersediaan sayur dan buah, pendapatan orang tua, dan tingkat pengetahuan orang tua. ${ }^{3,10}$

Pengenalan sayur dan buah dapat dikenalkan kepada anak saat memasuki usia 6 bulan atau ketika anak telah siap menerima MP ASI. Penelitian Tahun 2010, menyatakan bahwa pengenalan asupan sayur dan buah dapat dilakukan pada saat anak memasuki periode sensitif yaitu usia 4-6 bulan, karena anak lebih mudah dalam menerima makanan baru. ${ }^{13}$ Namun, penelitian meta-analisis Tahun 2016 menyatakan bahwa pengenalan MP ASI saat usia $\leq 4$ bulan dapat meningkatkan terjadinya overweight dan obesitas pada anak. ${ }^{14}$ Sesuai dengan penelitian cohort Tahun 2011, bayi yang dikenalkan dengan makanan padat $\leq 4$ bulan atau $<6$ bulan berhubungan terhadap terjadinya obesitas sebesar 6 kali pada usia 3 tahun. ${ }^{15}$ Hal ini dikarenakan MP ASI yang pada bayi saat usia $\leq 4$ bulan dapat meningkatkan asupan energi yang masuk. ${ }^{15}$ Pengenalan MP ASI saat usia $>6$ bulan juga tidak dianjurkan karena berisiko terjadinya picky eater pada anak sehingga berpengaruh terhadap asupan makan kedepannya. ${ }^{16}$

Penelitian Tahun 2014, menyatakan bahwa bayi yang dikenalkan dengan MP ASI saat usia 6 bulan memiliki asupan sayur dan buah yang lebih tinggi dari pada bayi yang terlambat diberikan MP ASI. Asupan makan sayur dan buah yang lebih bervariasi pada 2 tahun pertama berhubungan positif dengan variasi sayur dan buah pada usia 6, 7 dan 8 tahun berikutnya. ${ }^{16}$ Riwayat ASI eksklusif juga berpengaruh terhadap asupan sayur dan buah pada anak. ${ }^{12}$ Semakin lama pemberian ASI maka semakin tinggi pula asupan sayur dan buah pada anak, dan sebaliknya. ${ }^{17}$ Mekanisme pengenalan tersebut karena rasa dari asupan sayur dan buah yang dimakan oleh ibu saat masa kehamilan dapat diteruskan kepada janinnya melalui cairan amniotik dan selanjutnya diteruskan kembali setelah bayi mulai mengkonsumsi Air Susu Ibu (ASI). ${ }^{10,18}$ Berdasarkan latar belakang tersebut, akan dilakukan penelitian untuk mengetahui hubungan usia pengenalan sayur dan buah terhadap tingkat konsumsi sayur dan buah pada anak prasekolah usia 3-5 tahun.

\section{METODE}

Penelitian dilaksanakan di 2 Kelurahan wilayah kerja Pukesmas Kagok yaitu Kelurahan Wonotingal dan Kelurahan Candisari, Semarang. Lokasi penelitian ditetapkan berdasarkan prevalensi pemberian ASI eksklusif di Kagok Tahun 2014 sebesar $108,37 \% .{ }^{19}$ Ruang lingkup penelitian adalah penelitian bidang gizi masyarakat dan merupakan studi observasional dengan metode Cross-Sectional (belah lintang).

Populasi target pada penelitian adalah anak prasekolah usia 3-5 tahun. Berdasarkan perhitungan besar sampel menggunakan rumus korelasi Sokal dan Rohlf, didapat hasil sebanyak 53 subjek. Pengambilan data dilakukan di 11 posyandu yaitu 3 posyandu Kelurahan Wonotingal dan 8 posyandu 
Kelurahan Candisari. Teknik pengambilan data subjek penelitian dengan metode Consecutive Sampling dengan kriteria yaitu anak prasekolah usia 3-5 tahun, subjek penelitian memiliki riwayat ASI eksklusif dan ibu atau orang tua subjek bersedia menjadi responden penelitian.

Variabel dependen penelitian ini adalah tingkat konsumsi sayur dan buah pada anak prasekolah usia 3-5 tahun. Variabel independen adalah usia pengenalan sayur dan buah. Lama pemberian ASI, pendapatan orang tua dan ketersediaan sayur dan buah sebagai variabel perancu dalam penelitian.

Data tingkat konsumsi sayur adalah jumlah sayur yang dikonsumsi anak prasekolah selama 1 bulan terakhir, diukur dengan menggunakan SQ-FFQ (Semi-Quantitative Food Frequency Quesioner), dengan hasil ukur berupa satuan URT (penukar) kemudian dikonversi menjadi satuan gram. Standar 1 penukar sayur $=100 \mathrm{gr}$ atau setara dengan 1 gelas sayuran yang telah dimasak/ditiriskan. ${ }^{9}$ Data tingkat konsumsi buah adalah jumlah buah yang dikonsumsi anak prasekolah selama 1 bulan terakhir, diukur dengan menggunakan SQ-FFQ (Semi-Quantitative Food Frequency Quesioner), dengan hasil ukur berupa satuan URT (penukar) kemudian dikonversi menjadi satuan gram. Standar 1 penukar buah $=50$ gr atau setara dengan 1 buah pisang ambon ukuran sedang. ${ }^{9}$

Data usia pengenalan sayur dan buah merupakan usia ketika orang tua mulai mengenalkan sayur dan buah kepada anaknya pada awal pemberian MP ASI. Data ini didapat melalui wawancara menggunakan kuesioner usia pemberian MP-ASI. Data ketersediaan sayur adalah tersedianya sayur sebagai menu harian dalam jumlah yang cukup. Data tersebut diperoleh melalui kuesioner ketersediaan sayur dan buah sebagai menu harian, kemudian hasilnya dikategorikan baik apabila 2,5-3 penukar/hari dan kategori kurang apabila $<2,5-3$ penukar/hari. ${ }^{9}$ Data ketersediaan buah adalah tersedianya buah sebagai menu harian dalam jumlah yang cukup. Data diperoleh melalui kuesioner ketersediaan sayur dan buah sebagai menu harian, kemudian hasilnya dikategorikan baik apabila 1,5-2 penukari/hari dan kurang apabila $<1,5-2$ penukar/hari. ${ }^{9}$

Data lama pemberian ASI adalah lama waktu dalam pemberian ASI kepada bayi, diperoleh melalui wawancara dengan ibu responden. Data pendapatan orang tua merupakan pendapatan yang berasal dari orang tua yang bekerja, yang digunakan untuk memenuhi kemampuan daya beli pangan keluarga, tingkat ketersediaan serta keragaman konsumsi sayur dan buah pada anggota keluarga. Data pendapatan diperoleh melalui wawancara, kemudian dikategorikan menjadi 2 kelompok yaitu < UMR (<Rp 2.125.000,-) dan > UMR (>Rp 2.125.000,).

Analisis data menggunakan program SPSS versi 16. Data yang diperoleh diuji kenormalannya dengan menggunakan uji Kolmogorov-Smirnov (n $>50$ ). Analisis univariat digunakan untuk mengetahui gambaran karakteristik setiap variabel dalam penelitian. Analisis bivariat bertujuan untuk menganalisis hubungan antar variabel terikat (tingkat konsumsi sayur dan buah), dengan variabel bebas (usia pengenalan sayur dan buah) menggunakan uji korelasi Rank Spearman karena data berdistribusi tidak normal. Analisis multivariat digunakan untuk menganalisis hubungan yang paling erat antara beberapa variabel, yaitu variabel bebas, terikat dan variabel perancu, menggunakan uji regresi linier berganda.

\section{HASIL}

\section{Karakateristik Subjek Penelitian}

Sampel penelitian ini sebanyak 53 anak yang memiliki rentang usia anak 3-5 tahun, dengan ratarata usia anak adalah 4.02 tahun. Sebagian besar sampel berjenis kelamin perempuan yaitu 33 anak (62.3\%). Mayoritas ayah dari balita berprofesi sebagai karyawan swasta sedangkan ibu sebagai ibu rumah tangga.

Tabel 1. Distribusi Pendapatan Orang Tua, Lama Pemberian ASI dan Ketersediaan Sayur dan Buah

\begin{tabular}{ccc}
\hline Variabel & n & \% \\
\hline Pendapatan Orang Tua & & \\
<UMR (< Rp 2.125.000,-) & 32 & 60.4 \\
>UMR (>Rp 2.125.000,-) & 21 & 39.6 \\
Lama Pemberian ASI & & \\
6-12 bulan & 5 & 9.4 \\
13-18 bulan & 5 & 9.4 \\
19-24 bulan & 32 & 60.4 \\
$\quad>24$ bulan & 11 & 20.8 \\
Ketersediaan Sayur & & \\
$\quad<2,5$ penukar & 4 & 7.5 \\
> 2,5 penukar & 49 & 92.5 \\
Ketersediaan Buah & & \\
$\quad<1,5$ penukar & 12 & 22.6 \\
$\geq 1,5$ penukar & 41 & 77.4 \\
\hline
\end{tabular}

Tabel 1. menunjukkan bahwa sebanyak 32 orang tua subjek (60.4\%) memiliki pendapatan orang tua $<$ UMR $(<\mathrm{Rp} 2.125 .000,-)$. Lama pemberian ASI pada balita mayoritas diberikan pada rentang usia 1924 bulan $(60,4 \%)$. Ketersediaan sayur sebagai menu harian minimal disediakan sebesar $<2,5$ penukar/hari (7,5\%), sedangkan ketersediaan buah mayoritas disediakan sebanyak $\geq 1,5$ penukar/hari $(77,4 \%)$. 
Tabel 2. Distribusi Usia Pengenalan Sayur dan Buah dan Tingkat Konsumsi Sayur dan Buah

\begin{tabular}{lcccc}
\hline Variabel & Mean & Std. Deviasi & Max & Min \\
\hline Usia Pengenalan Sayur (bln) & 8.17 & 1.24 & 12 & 6 \\
Usia Pengenalan Buah (bln) & 7.60 & 1.60 & 12 & 6 \\
Tingkat Konsumsi Sayur & 84.78 & 57.72 & 243.30 & 10 \\
Tingkat Konsumsi Buah & 98.94 & 78.86 & 330.60 & 13 \\
\hline
\end{tabular}

Tabel 2. menunjukkan bahwa usia pengenalan sayur dan buah pada anak memiliki rentang usia yang bervariasi antara 6-12 bulan dengan rerata usia pengenalan sayur 8,17 bulan dan 7,6 bulan untuk usia pengenalan buah. Rerata tingkat konsumsi sayur pada anak sebesar 84,78 gr dan 98,94 gr untuk tingkat asupan buah.

Hubungan Usia Pengenalan Sayur, Lama Pemberian ASI, Pendapatan Orang Tua dan Ketersediaan Sayur dengan Tingkat Konsumsi Sayur

Analisis hubungan antar variabel dilakukan dengan tingkat konsumsi sayur menggunakan uji Rank Spearman, hasil analisis disajikan dalam tabel sebagai berikut :

Tabel 3. Hubungan Usia Pengenalan Sayur, Lama Pemberian ASI, Pendapatan Orang Tua dan Ketersediaan Sayur dengan Tingkat Konsumsi Sayur

\begin{tabular}{lcc}
\hline \multirow{2}{*}{ Variabel } & \multicolumn{2}{c}{ Tingkat Konsumsi Sayur } \\
\cline { 2 - 3 } & $\mathbf{r}$ & $\boldsymbol{p}$ \\
\hline Usia Pengenalan Sayur & $-0,182$ & 0,193 \\
Lama Pemberian ASI & $-0,53$ & 0,707 \\
Pendapatan Orang Tua & 0,136 & 0,331 \\
Ketersediaan Sayur & $-0,033$ & 0,816
\end{tabular}

Keterangan $=p:$ nilai signifikansi, $r:$ koefisien korelasi dan $(*)$ : berhubungan $(p<0.05)$.

Tabel 3. menunjukkan bahwa tidak terdapat hubungan yang signifikan antara usia pengenalan sayur, lama pemberian ASI, pendapatan orang tua dan ketersediaan sayur dengan tingkat konsumsi sayur pada anak prasekolah usia 3-5 tahun.

Hubungan Usia Pengenalan Buah, Lama Pemberian ASI, Pendapatan Orang Tua dan

\section{Ketersediaan Buah dengan Tingkat Konsumsi} Buah

Analisis hubungan antar variabel dilakukan dengan tingkat konsumsi buah menggunakan uji Rank Spearman, hasil analisis disajikan dalam tabel sebagai berikut :

Tabel 4. Hubungan Usia Pengenalan Buah, Lama Pemberian ASI, Pendapatan Orang Tua dan Ketersediaan Buah dengan Tingkat Konsumsi Buah

\begin{tabular}{lcc}
\hline \multicolumn{1}{c}{ Variabel } & \multicolumn{2}{c}{ Tingkat Konsumsi } \\
& Buah \\
\cline { 2 - 3 } & $\mathbf{r}$ & $\boldsymbol{p}$ \\
\hline Usia Pengenalan Buah & $-0,276$ & $0,045^{*}$ \\
Lama Pemberian ASI & 0,051 & 0,717 \\
Pendapatan Orang Tua & 0,260 & 0,060 \\
Ketersediaan Buah & 0,557 & $0,001^{*}$ \\
\hline
\end{tabular}

$\overline{\text { Keterangan }=p: \text { nilai signifikansi, } r: \text { koefisien korelas } i}$ dan $\left(^{*}\right)$ : berhubungan $(p<0.05)$.

Tabel 4. menunjukkan bahwa terdapat hubungan yang signifikan antara usia pengenalan buah dan ketersediaan buah dengan tingkat konsumsi buah pada anak prasekolah usia 3-5 tahun. Sebaliknya antara lama pemberian ASI dan pendapatan orang tua tidak berhubungan dengan tingkat konsumsi buah pada anak usia 3-5 tahun.

Faktor yang Mempengaruhi Tingkat Konsumsi Buah pada Anak Prasekolah

Sebesar 20,5\% ketersediaan buah berpengaruh terhadap tingkat konsumsi buah pada anak prasekolah usia 3-5 tahun. Setiap bertambahnya 1 penukar buah yang tersedia maka akan menaikkan tingkat konsumsi buah pada anak prasekolah sebesar 80.306 gram.

Tabel 5. Uji Regresi Ketersediaan Buah dengan Tingkat Konsumsi Buah

\begin{tabular}{cccc}
\hline Variabel & $\begin{array}{c}\text { Beta (Unstandarized } \\
\text { Coefficients) }\end{array}$ & $\boldsymbol{p}$ value & Adjusted R Square \\
\hline Constant & 41.507 & 0.273 & \\
Ketersediaan Buah & 80.306 & 0.001 & 0.205 \\
\hline
\end{tabular}

Keterangan $=p$ value: nilai signifikansi hubungan $(p<0.05)$.

\section{PEMBAHASAN}

Hasil penelitian menunjukkan bahwa tidak terdapat hubungan yang signifikan antara usia pengenalan sayur dengan tingkat konsumsi sayur pada anak prasekolah usia 3-5 tahun $(p=0,193)$. Rata-rata konsumsi sayur anak prasekolah sebesar
84,78 gr/hari, dimana jumlah ini masih tergolong kurang karena dibawah dari anjuran konsumsi sayur perhari yaitu 250 gram/hari. ${ }^{8}$ Kebiasaan dari orang tua yang hanya mengenalkan sayur yang mereka kenal dan sering makan menyebabkan rendahnya jumlah asupan sayur pada anaknya. Sesuai dengan 
penelitian Walker, makanan dapat tidak disukai atau dihindari oleh anak apabila orang tuanya tidak pernah memakan makanan tersebut. ${ }^{20}$ Pengaruh orang tua juga berperan terhadap pilihan makan, sikap dan kepercayaan tentang makanan karena orang tua akan memutuskan tentang tipe atau jenis makanan yang akan dikonsumsi oleh anak tersebut. ${ }^{13}$ Selain itu, adanya perbedaan sensitivitas anak terhadap rasa pahit akibat kandungan zat phenylthiocarbamide pada sayuran, menyebabkan anak yang kurang sensitif pada rasa pahit akan lebih menerima asupan sayur dibandingkan yang lebih sensitif. ${ }^{10}$

Lama pemberian ASI tidak berhubungan dengan tingkat konsumsi sayur pada anak prasekolah usia 3-5 tahun $(p=0,707)$, dengan nilai korelasi 0,53 . Hal ini ditunjukkan bahwa 6 sampel dengan riwayat lama pemberian ASI selama >24 bulan memiliki rata-rata tingkat konsumsi sayur yang rendah yaitu sebesar 39,78 gram/hari. Artinya bahwa semakin lama pemberian ASI maka semakin rendah tingkat konsumsi sayur pada anak prasekolah.

ASI berperan dalam transfer rasa sayur dari ibu kepada anaknya, namun apabila diberikan $>24$ bulan maka akan berdampak terhadap penerimaan anak pada MP-ASI yang diberikan. Hal ini akibat penolakan terhadap makanan baru (neophobia) tersebut merupakan respon normal yang berpuncak pada usia sekitar 20 bulan, dan secara bertahap akan berkurang pada usia sekitar 8 tahun. ${ }^{21}$ Selain itu, neophobia juga dikaitkan dengan respon sensitif terhadap rasa atau bau dari makanan bukan dari penampilan makanan. ${ }^{22}$

Pendapatan orang tua tidak berhubungan dengan tingkat konsumsi sayur pada anak prasekolah. Hal ini berarti tingginya tingkat pendapatan orang tua tidak diikuti dengan semakin banyaknya jumlah sayur yang dikonsumsi oleh anak prasekolah. Sesuai dengan penelitian tahun 2014, bahwa tidak terdapat hubungan yang signifikan antara pendapatan orang tua dengan konsumsi sayur. ${ }^{23}$ Konsumsi sayuran tidak berpengaruh terhadap pendapatan karena harga sayuran yang relatif terjangkau di kalangan masyarakat dengan tingkat ekonomi menengah kebawah maupun menengah keatas. ${ }^{24}$

Tidak terdapat hubungan antara ketersediaan sayur dengan tingkat konsumsi sayur pada anak prasekolah usia 3-5 tahun $(p=0,816)$. Hal ini menunjukkan bahwa tersedianya sayuran di rumah belum tentu dikonsumsi oleh anak. Sejalan dengan penelitian Tahun 2002 pada remaja di Amerika, menyatakan bahwa ketersediaan makanan di rumah tangga tidak berhubungan dengan konsumsi sayur pada remaja dan berdampak kecil terhadap kecenderungan dalam mengonsumsi sayur. ${ }^{24}$

Usia pengenalan buah berhubungan dengan tingkat konsumsi buah ( $p=0,045)$ pada anak prasekolah usia 3-5 tahun, dengan rata-rata konsumsi buah sebesar 98,94 gr/hari yang masih dalam kategori kurang. Sesuai penelitian Tahun 2014, bahwa bayi yang dikenalkan dengan MP-ASI saat usia 6 bulan memiliki asupan buah yang lebih tinggi dari pada bayi yang terlambat diberikan MP ASI. ${ }^{16}$ Selain itu, usia 6 bulan merupakan periode sensitif karena masa dimana anak lebih mudah dalam menerima makanan baru. ${ }^{13}$ Sejalan dengan arah korelasi negatif atau berlawanan dari usia pengenalan buah, artinya semakin dini usia pengenalan buah (dimulai dari usia 6 bulan) maka semakin tinggi pula tingkat konsumsi buah pada anak prasekolah usia 3-5 tahun. Sesuai penelitian Cooke et al., bahwa ada hubungan antara usia pengenalan dengan konsumsi buah pada anak usia 11 tahun. ${ }^{18}$

Lama pemberian ASI tidak berhubungan dengan tingkat konsumsi buah ( $p=0,717$ ). Namun, lama pemerian ASI memiliki arah korelasi positif, yang artinya bahwa semakin lama pemberian ASI maka semakin tinggi tingkat konsumsi buah pada anak prasekolah usia 3-5 tahun. Sesuai dengan penelitian Tahun 2012 yang menyatakan bahwa lama pemberian ASI berhubungan dengan tingginya asupan buah pada anak..$^{25}$ Proses tranfer rasa asupan buah berasal dari asupan buah yang dikonsumsi ibu balita, kemudian rasa buah tersebut akan disalurkan kepada anaknya melalui ASI. ${ }^{10}$ Mennella dkk. (2001) menyatakan bahwa pengenalan awal rasa yang diperoleh melalui menyusui dapat meningkatkan penerimaan rasa makanan yang lebih luas selama masa penyapihan dan selama masa kanak-kanak. ${ }^{17}$ Selain itu, anak yang mendapat ASI cenderung tidak pemilih dalam makanan serta lebih menerima apabila dikenalkan dengan makanan baru. ${ }^{26}$

Berbeda dengan balita yang mendapatkan ASI eksklusif sampai 6 bulan dan dilanjutkan sampai usia 2 tahun, balita yang mendapat ASI $<6$ bulan biasanya cenderung menolak asupan sayur dan buah. Hal ini karena kurang familiarnya balita terhadap rasa dari asupan sayur maupun buah yang dikenalkan sehingga mereka menganggap asupan tersebut sebagai makanan baru dan menolak untuk mengkonsumsi asupan tersebut. Sesuai dengan penelitian Laureati M,et.al menyatakan bahwa anak yang neophobia (menolak makanan baru) berhubungan negatif dengan asupan sayur dan buah. ${ }^{27}$ Namun, perilaku neophobia terhadap makanan baru merupakan bagian dari perkembangan normal pada anak, bukan merupakan perilaku tidak suka secara abadi melainkan tidak suka secara sementara yang dapat diubah melalui kebiasaan. ${ }^{14}$

Pendapatan orang tua tidak berhubungan dengan tingkat konsumsi buah pada anak prasekolah usia 3-5 tahun. Tingginya tingkat pendapatan orang tua tidak diikuti dengan semakin banyaknya jumlah 
sayur dan buah yang dikonsumsi oleh anak prasekolah. Sesuai dengan penelitian tahun 2014, bahwa tidak terdapat hubungan yang signifikan antara pendapatan orangtua dengan konsumsi buah. ${ }^{23}$ Kebiasaan orang tua yang sering membeli buah dalam jumlah banyak untuk 3-5 hari kedepan atau hanya membeli 1 buah/hari sehingga tingkat konsumsi buah tidak terpengaruh oleh jumlah pendapatan orang tua. $^{28}$

Terdapat hubungan yang positif antara ketersediaan buah dengan tingkat konsumsi buah pada anak prasekolah usia 3-5 tahun. Hal ini berarti bahwa peningkatan ketersediaan buah di rumah berbanding lurus dengan peningkatan konsumsi buah pada anak prasekolah. Berdasarkan hasil analisis regresi linier berganda bahwa sebesar 20,5\% ketersediaan buah berpengaruh terhadap tingkat konsumsi buah pada anak prasekolah usia 3-5 tahun. Sesuai penelitian Bourdeaudhuij et al., menunjukkan bahwa terdapat hubungan yang signifikan antara ketersediaan buah di rumah dengan tingkat konsumsi buah pada anak. ${ }^{28}$

\section{SIMPULAN}

Tidak terdapat hubungan antara usia pengenalan sayur dengan tingkat konsumsi sayur, sedangkan usia pengenalan buah berhubungan negatif dengan tingkat konsumsi buah pada anak prasekolah usia 3-5 tahun.

\section{SARAN}

1. Untuk meningkatkan konsumsi sayur dan buah pada anak, sebaiknya wanita usia prakonsepsi, ibu hamil dan menyusui dapat memulai meningkatkan konsumsi sayur dan buah.

2. Ketersediaan sayur dan buah di rumah setidaknya sejumlah 5 penukar/hari, dimana 2,5-3 penukar untuk sayur dan 1,5-2 penukar untuk buah.

3. Karena keterbatasan waktu sebaiknya penelitian selanjutnya menggunakan desain Cohort dengan sampel ibu hamil. Kebiasaan makan sayur dan buah saat ibu hamil diikuti sampai kepada saat anaknya usia prasekolah dan dilihat juga kebiasaan makan sayur dan buah pada anaknya.

\section{UCAPAN TERIMA KASIH}

Terima kasih saya ucapkan kepada Allah SWT, Orang tua, dosen pembimbing, Pukesmas Kagok Semarang, Kader Posyandu Kelurahan Wonotingal dan Kelurahan Candisari serta pihak-pihak lain yang telah ikut berpartisipasi dalam penelitian ini.

\section{DAFTAR PUSTAKA}

1 Brown JE. Nutrition Through the Life Cycle. 4th ed. Cengage Learning: USA, 2011.

2 Saraswati T. Gambaran Perilaku Picky Eater dan
Faktor yang Melatar Belakanginya pada Siswa PAUD Kasih Ananda Bekasi. FKM, UI. 2012.

3 Vereecken C, Rovner A, Maes L. Associations of parenting styles, parental feeding practices and child characteristics with young children's fruit and vegetable consumption $\S$. Appetite 2010; 55: 589-596.

4 Connor TMO, Hughes SO, Watson KB, Baranowski T, Theresa A, Fisher JO et al. Parenting practices are associated with fruit and vegetable consumption in preschool children. NIH Public Access 2010; 13: 91-101.

5 Liska Widiyastuti. Intervensi Hidden Vegetable terhadap Penerimaan Sayuran pada Anak Prasekolah di TK PGRI 21 Karangasem Kota Semarang. Gizi FK UNDIP 2015; : 1-25.

6 Caton S, Sofia B, Hausner H, Hetherington M. Eating a Rainbow . Introducing vegetables in the first years of life in 3 European countries. Appetite 2013; 71: 48-56.

7 Rolfes SR, Pinna K, Whitney E. Understanding Normal and Clinical Nutrition. 8th ed. Cengage Learning: USA, 2009.

8 Miniarti E, Jafar N, Salam A. Gambaran Pengetahuan Ibu, Sikap Ibu, dan Pola Konsumsi Sayur dan Buah pada Anak Prasekolah di Kabupaten Toraja Utara. 2013.

9 Kemenkes RI. Pedoman Gizi Seimbang. Kemenkes RI 2014; : 33-35.

10 Mennella JA. Vegetable and Fruit Acceptance during Infancy: Impact of Ontogeny, Genetics , and Early Experiences Vegetable and Fruit Acceptance during Infancy: Impact of Ontogeny, Genetics, and Early. Adv Nutr 2016; 7: 211-219.

11 Benton D. Role of parents in the determination of the food preferences of children and the development of obesity. Inter J Obes 2004; 28: 858-869.

12 Hetherington MM, Schwartz C, Madrelle J, Croden F, Nekitsing C. A step-by-step introduction to vegetables at the beginning of complementary feeding. The effects of early and repeated exposure. Appetite 2015; 84: 280290.

13 Jones LR, Steer CD, Rogers IS, Emmett PM. Influences on child fruit and vegetable intake : sociodemographic , parental and child factors in a longitudinal cohort study. Public Health Nutr 2010; 13: 1122-1130.

14 Wang J, Wu Y, Xiong G, Chao T, Jin Q, Liu R. Introduction of complementary feeding before 4 months of age increases the risk of childhood overweight or obesity : a meta-analysis of prospective cohort studies. J Nutr Res 2016; 36: 1-12.

15 Huh SY, Rifas- SL, Taveras EM, Oken E, Gillman MW. Timing of Solid Food Introduction and Risk of Obesity in Preschool-Aged Children. Pedriatrics 2011; 127: 544-551.

16 Jones L, Moschonis G, Oliveira A, Lauzon-guillain B De, Manios Y, Xepapadaki P et al. The influence of early feeding practices on healthy diet variety score among pre-school children in four European birth cohorts. Public Health Nutr 2014; 18: 1774-1784.

17 Burnier D, Dubois L, Girard M. Exclusive breastfeeding duration and later intake of vegetables in preschool children. Eur J Clin Nutr 2011; 65: 196-202.

18 Cooke LJ, Wardle J, Gibson EL, Sapochnik M, Sheiham A, Lawson M. Demographic, familial and trait 
predictors of fruit and vegetable consumption by preschool children. Public Health Nutr 2003; 7: 295-302.

19 Dinkes. PROFIL KESEHATAN KOTA SEMARANG 2014. Dinas Kesehat Semarang 2014; : 82-83.

20 Febriana R, Masyarakat DG. Kebiasaan makan sayur dan buah ibu saat kehamilan kaitannya dengan konsumsi sayur dan buah anak usia prasekolah. $J$ Pangan Gizi 2014; 9: 133-138.

21 ITF. Developmental Stages in Infant and Toodler Feeding. In: Infant and Toodler Forum. 2014, pp 1-12.

22 Farrow CV CH. Relationships between sensory sensitivity, anxiety and selective eating in children. Appetite 2012; 44: 1-25.

23 Attorp A, Scott JE, Yew AC, Rhodes RE, Barr SI, Naylor P. Associations between socioeconomic , parental and home environment factors and fruit and vegetable consumption of children in grades five and six in British Columbia , Canada. BMC Public Health 2014; 14: 1-9.

24 Mohammad A, Madanijah S. Konsumsi Buah dan Sayur Anak Usia Sekolah Dasar di Bogor. J Gizi Pangan 2015; 10: 71-76.

25 Lauzon-guillain B De, Jones L, Oliveira A, Moschonis $\mathrm{G}$, Betoko A, Lopes C et al. The influence of early feeding practices on fruit and vegetable intake among preschool children in 4 European birth cohorts $1-3$. Am J Clin Nutr 2013; 98: 804-813.

26 Mennella JA. Ontogeny of taste preferences: basic biology and implications for. Am J Clin Nutr 2014; 99: 704-711.

27 Laureati M, Bertoli S, Bergamaschi V, Leone A, Lewandowski L, Giussani B et al. Food neophobia and liking for fruits and vegetables are not related to Italian children' s overweight. Food Qual Prefer 2015; 40: 125-131.

28 Kristjansdottir AG, Thorsdottir I, Bourdeaudhuij I De, Due P, Wind M, Klepp K. Determinants of fruit and vegetable intake among 11-year-old schoolchildren in a country of traditionally low fruit and vegetable consumption. Int J Behav Nutr Phys Act 2006; 9: 1-9. 